\title{
Bacterial activity and diffusive nutrient supply in the oligotrophic Central Atlantic Ocean
}

\author{
Josep M. Gasol ${ }^{1, *}$, Evaristo Vázquez-Domínguez ${ }^{1}$, Dolors Vaqué ${ }^{1}$, Susana Agustí ${ }^{2}$, \\ Carlos M. Duarte ${ }^{2}$
}

${ }^{1}$ Departament de Biologia Marina i d'Oceanografia, Institut de Ciències del Mar-CSIC. Pg. Marítim de la Barceloneta 39-47,
08003 Barcelona, Catalunya, Spain

${ }^{2}$ IMEDEA (CSIC-UIB), Institut Mediterrani d'Estudis Avançats, c. Miquel Marquès 21, 07190 Esporles, Mallorca, Spain

\begin{abstract}
Growing evidence of inorganic nutrient limitation on oceanic bacteria suggests a global dependence of bacterial activity and production on rates of nutrient supply. The present study examined whether surface bacterial abundance is significantly related to water column stability, and whether bacterial activity and growth rate are related to the rate of diffusive supply of inorganic nutrients to the mixed layer in the Central Atlantic during 2 meridional cruises. The 2 cruises were run under very different oceanic conditions, with relatively low values of bacterial activity in spring 1995 and relatively higher values in fall 1995. We obtained depth-resolved data in the second cruise and found that the integrated value of bacterial production was also related to the rate of nutrient supply, while integrated particulate primary production and chlorophyll concentration were not. There was also no relationship between particulate primary production and bacterial production. The relationship between nutrient supply and integrated bacterial production was tested with data from a mesocosm experiment showing a good fit to the pattern obtained in the Atlantic. Average bacterial production was $\sim 21 \%$ of primary production in the Central Atlantic, with values ranging between 5 and $100 \%$, and higher values in the tropical areas. The demonstration of a direct relationship between nutrient supply and bacterial activity helps to explain a relatively large bacterial biomass as compared to phytoplankton biomass, a low bacterial growth efficiency, and a high bacterial carbon demand relative to contemporaneous primary production often measured in the open ocean, as well as the accumulation of dissolved organic carbon (DOC) observed in nutrient-limited oligotrophic seas.
\end{abstract}

KEY WORDS: Bacterial activity $\cdot$ Bacterial production $\cdot$ Central Atlantic $\cdot$ Nutrient supply $\cdot$ Primary production $\cdot$ Water column stability $\cdot$ Mediterranean mesocosms

\section{INTRODUCTION}

Heterotrophic bacteria and archaea are key components of the planktonic food web, dominating total biomass and heterotrophic activity in the oligotrophic ocean (Gasol et al. 1997, del Giorgio et al. 1997). A growing body of evidence points to order-of-magnitude variability in bacterial production in the ocean (e.g. Hoppe et al. 2002). The drivers for this variability are suggested to include variability in primary production both at the local, regional (Hoppe et al. 2002) and global scales (Cole et al. 1988). A direct relationship between bacterial production and primary production is thought to be a consequence of a direct dependence of bacteria on the concurrent activity of the primary producers through the production of labile dissolved organic carbon (DOC). Consequently, the linkage of primary production to bacterial activity in the oligotrophic ocean is a well-accepted paradigm.

But bacteria use carbon from sources other than concurrent primary production (Nagata 2000). Cherrier et al. (1999) showed that oceanic bacteria could satisfy part of their carbon requirements through the use of old (i.e. non-contemporaneously produced) DOC. The 
oceanic DOC pool is large, yet, in degradation experiments, bacteria use only a minor fraction of the total DOC pool (Carlson \& Ducklow 1996), suggesting that only a small fraction of this nutrient-depleted (Hansell \& Waterhouse 1997) and old (cf. Williams \& Druffel 1987) pool is available to bacteria. While recently produced DOC seems to be readily available (Norrman et al. 1995), this represents a minor fraction of the DOC pool (i.e. never more than $40 \%$, Teira et al. 2001). There is a larger fraction of DOC, deemed 'semi-labile' DOC, comprising about $17 \%$ of the total DOC pool in oceanic waters (del Giorgio \& Davis 2002) that might be used by bacteria, depending on external conditions. In particular, there is experimental evidence that the supply of inorganic nutrients facilitates the use of semilabile DOC (Zweifel et al. 1993, Thingstad et al. 1997). This has led to the hypothesis that inorganic nutrient limitation restricts bacterial DOC use in the ocean (Cotner et al. 1997) and, as a corollary, that there should be a link between nutrient supply and bacterial activity in the ocean. While some published experiments do not support this hypothesis (Carlson \& Ducklow 1996, Carlson et al. 2002, 2004), the possible role of inorganic nutrient supply in explaining the variability in bacterial activity in the open ocean remains largely untested.

Additionally, there is growing evidence, particularly for the Atlantic Ocean (Agustí et al. 2001, Duarte et al. 2001, Hoppe et al. 2002), that bacterial production may actually exceed that possible from the concurrent carbon supply from phytoplankton, suggesting that bacteria and phytoplankton may not be as tightly linked in the oligotrophic ocean as currently assumed. Evidence has been collected that suggests bacteria in the Atlantic Ocean (Pomeroy et al. 1995, Cotner et al. 1997, Rivkin \& Anderson 1997, Alonso-Sáez et al. 2007) and elsewhere (Zohary \& Robarts 1998, Thingstad et al. 1998, Zohary et al. 2005) are limited by inorganic nutrients, mainly $\mathrm{P}$, thus suggesting that the supply of these resources could explain variability in bacterial activity.

In the present study, we compare the dependence of bacterial activity on phytoplankton biomass and activity to that between bacterial activity and nutrient supply, at least in accounting for basin-scale variability in bacterial production in the Central Atlantic Ocean. We do so on the basis of estimates of bacterial activity and the diffusive supply of inorganic nutrients across the thermocline in 2 meridional cruises along the 5 oceanic provinces in the Central Atlantic, encompassing a range of bacterial abundance and activity comparable to the full range encountered in the open ocean. We also test the relationship between particulate primary production and the diffusive nutrient supply to evaluate whether the hypothesized relationship with bacterial activity may derive indirectly from a link between nutrient supply and primary production. The robustness of the relationship between bacterial production and nutrient supply derived from the analysis of Central Atlantic data is further tested using data derived from a mesocosm experiment involving nutrient additions to an oligotrophic coastal community (cf. Duarte et al. 2000). We then examine the implications of the relationship for the uncoupling between concurrent bacterial and particulate phytoplankton production and its possible impact on ecosystem function.

\section{MATERIALS AND METHODS}

Data were collected in meridional cruises along the central Atlantic Ocean aboard the Spanish RV 'Hespérides,' in March to April 1995 (Latitud-I cruise) and October to November 1995 (Latitud-II cruise). The cruises sampled mostly the same water and their courses were similar (in the southern hemisphere; Fig. 1) with the exception of the northern hemisphere, where in the Latitud-II we sampled the more eutrophic waters close to the African coastline. A total of $\sim 100$ stations were occupied (Fig. 1), where bacterial activity was measured in surface $(5 \mathrm{~m})$ waters (both cruises) and in vertical profiles during Latitud-II. During Latitud-II, and in samples taken at noon, we also measured primary production. Simultaneous to all measurements, we determined the vertical profiles of temperature, salinity, horizontal velocity and nutrient concentrations, which were used to parameterize the diffusive vertical nutrient flux across the thermocline. This is believed to be one of the major sources of nutrients in the oligotrophic ocean, particularly in gyre areas (Lewis et al. 1986). It is not the only source, however, since nitrogen fixation, atmospheric deposition (Prospero et al. 1996, Duarte et al. 2006) and lateral inputs (e.g. McGillicuddy et al. 1998) may also be significant. Hence, the estimates of nutrient supply provided by the diffusive vertical nutrient flux across the thermocline are conservative.

Oceanographic data and calculations. Conductivitytemperature-pressure (Mark III or Mark V, SeaBird) data were obtained with a vertical resolution of $10 \mathrm{~cm}$, and processed as previously described (e.g. Vidal et al. 1999, Agustí et al. 2001). Horizontal velocity was measured continuously along the cruise using a VM150 narrow-band acoustic Doppler current profiler (RD Instruments) mounted on the mid-hull of the ship. Water samples were collected using a rosette sampler system fitted with twenty-four 12 l Niskin bottles attached to the CTD from a total of 17 to 18 depths at each station, with a higher density of samples at the thermocline, where changes in nutrient concentrations were greatest. Chlorophyll a ( $\mathrm{chl}$ a) concentration was 

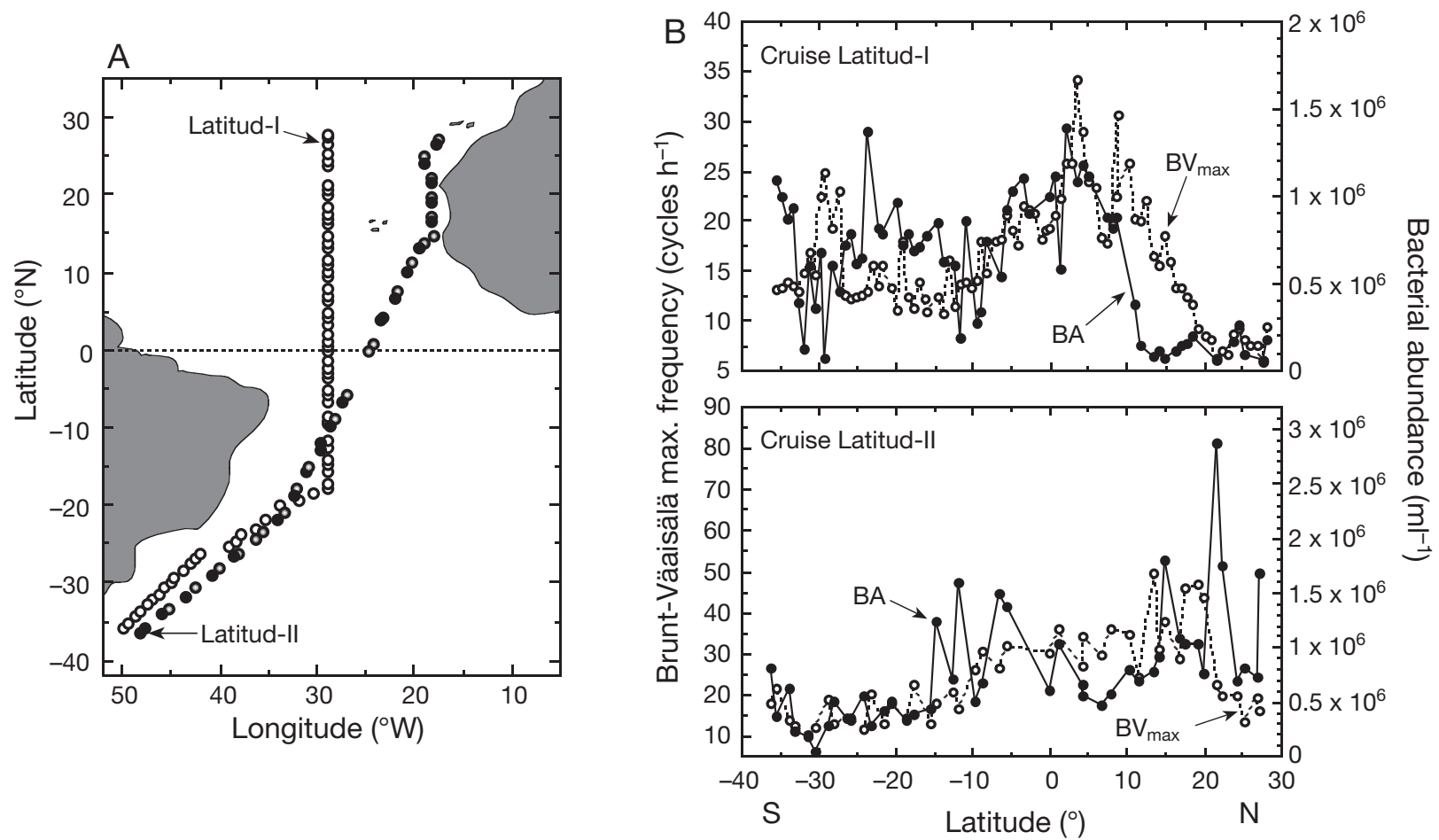

Fig. 1. (A) Stations sampled during the 2 cruises. For the October-November (Latitud-II) cruise, the stations where primary production was determined are indicated as dark points. (B) Water column stability, as the maximal Brunt-Väisälä frequency (BV max) at the thermocline, and bacterial abundance (BA) in surface waters of the stations sampled in the 2 cruises. Pearson correlation coefficient between total $\mathrm{BA}$ and the $\mathrm{BV}_{\max }, \mathrm{r}=0.35(\mathrm{n}=107, \mathrm{p}=0.0002)$

measured fluorometrically and the concentration of dissolved inorganic $\left(\mathrm{PO}_{4}^{3-}, \mathrm{NO}_{3}^{-}+\mathrm{NO}_{2}^{-}\right)$nutrients were measured spectrophotometrically, or using an autoanalyzer when concentrations were high, following standard methods (cf. Vidal et al. 1999). The detection limits of dissolved nutrient concentrations were 5 and $10 \mathrm{nM}$ for spectrophotometric determinations of $\mathrm{NO}_{3}{ }^{-}+\mathrm{NO}_{2}^{-}$and $\mathrm{PO}_{4}{ }^{3-}$, respectively, and $20 \mathrm{nM}$ for $\mathrm{NO}_{3}{ }^{-}+\mathrm{NO}_{2}{ }^{-}$measured with the autoanalyzer.

The vertical gradient in $\sigma \mathrm{t}$ was used to calculate the Brunt-Väisälä buoyancy frequency $(\mathrm{N})$, and the average vertical velocity profiles obtained for each station were used to calculate vertical shear. $\mathrm{N}$ and the vertical shear estimates were combined to derive an estimate of the vertical diffusivity across the thermocline, following the parameterization developed by Granata et al. (1995). The thermocline depth was defined as the depth at which maximum stratification occurred (i.e. maximum N). We found this depth corresponded closely to the depth of the euphotic layer (where irradiance $=1 \%$ of that at the surface) across the transect (Agustí \& Duarte 1999). Areally integrated pools and fluxes within the biogenic zone were therefore computed by vertical integration from the water surface to the thermocline depth, as defined above. The turbulent flux of dissolved inorganic nutrients into the biogenic layer was calculated, assuming Fickian transport, as the product between the coefficient of vertical diffusivity and the gradient in nutrient concentration across the thermocline (Lewis et al. 1986). The error in determining the diffusive nutrient fluxes cannot be directly resolved, as this would require accurate and precise independent estimates, but is believed to be about an order of magnitude. The estimates of the diffusive nutrient fluxes combine an estimate of the nutrient gradient across the upper thermocline, typically resolved with a $10 \%$ uncertainty, with estimates of the vertical turbulent diffusivity coefficient, which is subject to much larger uncertainties (Osborn 1980). Hence, the error is dominated by error in the vertical turbulent diffusivity coefficient, which is typically an order of magnitude in size (Osborn 1980). Accordingly, the estimates of the turbulent flux of dissolved inorganic nutrients reported here involve that level of uncertainty.

Biological processes. Particulate primary production was measured in situ at the stations occupied in the Latitud-II cruise only, before noon. It was estimated as ${ }^{14} \mathrm{C}$ - incorporation into organic material collected on a filter (particulate primary production) following standard procedures, and as explained elsewhere (Agustí et al. 2001). We collected water samples from discrete depths (about 7 depths extending from subsurface 
waters to the bottom of the photic layer), transferred them to $125 \mathrm{ml}$ Pyrex glass bottles and added $\mathrm{NaH}^{14} \mathrm{CO}_{3}$ in concentrations between 80 and $650 \mu \mathrm{Ci}$ $\mathrm{l}^{-1}$, depending on the chl a concentration. Samples consisting of duplicate light samples and 1 dark bottle were incubated in situ, suspended from a free-drifting buoy at their respective depths for 1.5 to $3 \mathrm{~h}$ (a duration similar to that used for bacterial activity measurements). After incubation, the samples were filtered onto Whatman glass fiber filters (GF/F) at low pressure (below $0.3 \mathrm{Kbar}$ ) and the filters were placed in scintillation vials with $50 \mu \mathrm{l} 2 \mathrm{M} \mathrm{HCl}$ and allowed to evaporate for $24 \mathrm{~h}$. Filters were submersed in $10 \mathrm{ml}$ of scintillation liquid (Ecoscint $\mathrm{H}$, National Diagnostics) and kept in the dark for $24 \mathrm{~h}$ before counting on a Beckman liquid scintillation counter. Daily, 24 h, particulate primary production was calculated by multiplying the hourly rates measured by the number of daylight hours.

We fixed $100 \mathrm{ml}$ subsamples from each depth with cold glutaraldehyde ( $1 \%$, final concentration) for DAPI counts of bacteria by epifluorescence microscopy. All filtration was performed on the day of collection or the next day. Between 15 and $20 \mathrm{ml}$ were filtered through $0.2 \mu \mathrm{m}$ black polycarbonate filters to estimate bacterial abundance, stained with $0.1 \mu \mathrm{g}$ DAPI ml ${ }^{-1}$ final concentration for $5 \mathrm{~min}$ and mounted on microscope slides with non-fluorescent oil. The filters were kept frozen until microscopic inspection, which occurred within 2 mo of sampling. At least 200 to 400 cells per sample were counted and their length and width measured under the microscope. During the Latitud-II cruise, subsamples $(1.2 \mathrm{ml})$ were preserved with $1 \%$ paraformaldehyde $+0.05 \%$ glutaraldehyde (final concentration), frozen in liquid nitrogen and stored at $-20^{\circ} \mathrm{C}$ to determine picoalgal and bacterial abundance by flow cytometry. The samples were later thawed, and run without any stain at high speed (approx. $60 \mu \mathrm{l}$ $\mathrm{min}^{-1}$ ), with $10 \mu \mathrm{l}$ per sample of a $10^{-5} \mathrm{ml}^{-1}$ solution of yellow-green $0.92 \mu \mathrm{m}$ Polysciences latex beads as an internal standard, to enumerate Synechococcus and Prochlorococcus. Afterwards, the samples were stained for ca. 10 min with Syto13 (Molecular Probes) at $2.5 \mu \mathrm{M}$ and run through a Becton \& Dickinson FACScalibur flow cytometer, following Gasol \& del Giorgio (2000). A plot of FL1 (green fluorescence) vs. FL3 (red fluorescence) allowed the differentiation of photosynthetic from non-photosynthetic prokaryotes. Although the cytometric bacterial and DAPI counts were highly correlated when Prochlorococcus was subtracted from the DAPI counts, the values were not always coincident. We thus decided to use the DAPI-Prochlorococcus counts as our standard estimates of heterotrophic bacterial abundance. Bacterial biovolume was estimated from Syto13 fluorescence (Gasol \& del Giorgio
2000) and was converted to carbon using standard carbon to volume relationships.

We estimated bacterial activity from radioactive leucine incorporation (Kirchman et al. 1985). Samples were collected from the Niskin bottles and kept in polyethylene bottles in an opaque box with surface water until used for the uptake measurements (which occurred after $<30 \mathrm{~min}$ ). Two different variations of the method were used. During the Latitud-I cruise, we used the classic filtration method; during the Latitud-II cruise, this method was modified to be conducted in Eppendorf vials. In the first cruise, we added 20 to $40 \mathrm{nM}$ leucine to triplicate vials. This was a saturating concentration as found in 5 concentration-dependent incorporation experiments performed during both cruises. The commercial leucine solution was brought to $1 \mu \mathrm{M}$ with $0.2 \mu \mathrm{m}$ filtered autoclaved milliQ water and mixed with nonradioactive leucine at $10 \%$ hot, $90 \%$ cold. We used 1 formalin-killed sample as a control and 2 experimental replicates. The vials were placed in whirl-pack bags and incubated in the dark and in temperatures as close as possible to the original ones by either using running surface water, or water baths adjusted to the necessary temperatures. Incubations lasted 90 to $200 \mathrm{~min}$ in accordance with the results of linearity experiments. After incubation, the samples were killed with formalin and processed in standard ways. During the second cruise we followed the same protocol, except that controls were established with $50 \%$ TCA-killed samples; TCA was also used to terminate the incubations, and we used 2 killed controls and 4 experimental replicates. We did not rinse with ethanol. In both cases, we counted the samples onboard with a Beckman scintillation counter after $48 \mathrm{~h}$ of having added the cocktail. Desintegrations per minute (dpm) were calculated using the instruments $\mathrm{H}$ number. Both methods had been compared previously in our laboratory with Mediterranean Sea water and we found no significant differences between them, although blanks tended to be lower using the second method. Bacterial heterotrophic production was calculated as leucine incorporation rate $\times$ a conversion factor $(\mathrm{CF})$. We performed 7 conversion factor experiments, which consisted in following bacterial growth in $<0.6 \mu \mathrm{m}$-filtered seawater (polycarbonate filters), diluted 1:9 with $0.2 \mu \mathrm{m}$ filtered seawater and incubated in the dark in acidclean glass Pyrex bottles. Subsamples were taken for bacterial biomass and bacterial leucine incorporation measurements every $12 \mathrm{~h}$. Data were computed following the cumulative method, a method that maximizes use of the available data. The average value

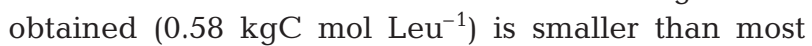
values commonly used (e.g. Hoppe et al. 2002 used 
$\left.1.5 \mathrm{kgC} \mathrm{mol} \mathrm{Leu}{ }^{-1}\right)$, but is in the normal range $(0.08$ to 1.21) of recent reports for the oligotrophic ocean (e.g. Zubkov et al. 2001, Alonso-Sáez et al. 2007). Specific growth rates were computed as bacterial production/bacterial biomass.

Mesocosm experiments in the Mediterranean. To test the predictive power of the relationship between bacterial production and nutrients derived from the cruises along the Central Atlantic, we conducted a mesocosm experiment involving a gradient of increasing nutrient inputs to the plankton community present in oligotrophic coastal waters. The experiment was done in June 1997 in the Bay of Blanes (the Blanes Bay Microbial Observatory, NW Mediterranean), when nutrient concentrations in the waters were low (dissolved inorganic nitrogen $<0.05 \mu \mathrm{M}$, phosphate = $0.01 \mu \mathrm{M})$. We used the estimate of the summer nutrient loading in the Bay of Blanes, about $5 \mathrm{mmol} \mathrm{N} \mathrm{m}^{-2} \mathrm{~d}^{-1}$ and $0.25 \mathrm{mmol} \mathrm{P} \mathrm{m}^{-2} \mathrm{~d}^{-1}$ (Duarte et al. 2000) to scale the nutrient inputs to the experimental mesocosms. Phosphorus and silicon were added to maintain their average summer stoichiometry with nitrogen in the sedimentary flux (20:7:1, N:Si:P) and nitrogen was added as ammonium, the dominant form of summer nitrogen input to Blanes Bay. We applied a gradation of nutrient inputs, from half to $1-, 2-, 4-, 8-$, and $16-$ times the estimated ambient nutrient loading, to a series of 6 large (effective volume $33 \mathrm{~m}^{3}$ ) mesocosms moored at $35 \mathrm{~m}$ depth, at about $2 \mathrm{~km}$ offshore from the town of Blanes. Nutrients were added to the mesocosms on alternate days during $3 \mathrm{wk}$, using solutions of $\mathrm{ClNH}_{4}, \mathrm{KH}_{2} \mathrm{PO}_{4}$, and $\mathrm{Na}_{2} \mathrm{SiF}_{6}$ in seawater. Bacterial production was estimated from integrated (0 to $12 \mathrm{~m}$ ) samples collected prior to the nutrient additions, processed as explained above, except that the standard
$3.1 \mathrm{kgC}$ mol $\mathrm{Leu}^{-1}$ was used to compute production. Additional details on the mesocosm design and experiment output are reported in Duarte et al. (2000).

\section{RESULTS}

The distribution of bacterial abundance in surface waters differed greatly between cruises (Table 1, Fig. 1), following a pattern similar to that of water column stability in each of the cruises (Fig. 1, Pearson correlation coefficient between bacterial abundance and maximal Brunt-Väisälä frequency at the thermocline, Pearson's $r=0.35, N=107, p=0.0002$ ). Bacterial production also ranged widely between cruises (Table 1) and was correlated to water column stability ( $p<$ 0.0005), despite the absence of significant correlation between bacterial abundance and activity ( $p=0.18$ ), indicative of strong variability in bacterial turnover (Table 1). The Latitud-I cruise was run under anomalously warm conditions - relative to the sea surface temperature average climatology (data not shown) while the Latitud-II cruise was characterized by rough waters and intense mixing, resulting in a considerably greater diffusive nutrient supply to the photic layer than that observed in the Latitud-I cruise (Table 1). Average mixed layer depth was also shallower during Latitud-II than Latitud-I $(36 \pm 1$ m vs. $43 \pm 3$, mean \pm $\mathrm{SE}$ ). Bacterial production in the first cruise was lower than previously reported for the Central Atlantic Ocean (e.g. Zubkov et al. 2000, Hoppe et al. 2002), while that during the Latitud-II cruise was greater than those previously reported.

We found a highly significant positive relationship between the diffusive vertical supply of inorganic

Table 1. Mean $( \pm \mathrm{SE})$ vertical turbulent diffusion coefficient $(\mathrm{Kz})$, vertical diffusive inorganic $\mathrm{P}$ and $\mathrm{N}$ fluxes, and chl a concentration (CHL), total prokaryote abundance (TP), and bacterial production (BP) and specific growth rates (SGR) in surface waters of the different regions occupied in the Latitud-I and II cruises. Partition of the Atlantic Ocean into biogeochemical provinces as: ST: Subtropical, T: Tropical, Eq: Equatorial, N: North, S: South

\begin{tabular}{|c|c|c|c|c|c|c|c|}
\hline Area & $\begin{array}{c}\mathrm{Kz} \\
\left(\mathrm{m}^{2} \mathrm{~d}^{-1}\right)\end{array}$ & $\begin{array}{c}\text { P flux } \\
\left(\mathrm{mmol} \mathrm{m}^{-2} \mathrm{~d}^{-1}\right)\end{array}$ & $\begin{array}{c}\mathrm{N} \text { flux } \\
\left(\mathrm{mmol} \mathrm{m}^{-2} \mathrm{~d}^{-1}\right)\end{array}$ & $\begin{array}{c}\mathrm{CHL} \\
\left(\mathrm{mg} \mathrm{m}^{-3}\right)\end{array}$ & $\begin{array}{c}\text { TP } \\
\left(10^{8} \text { cells } 1^{-1}\right)\end{array}$ & $\begin{array}{c}\text { BP } \\
\left(\mu g \mathrm{Cl}^{-1} \mathrm{~d}^{-1}\right)\end{array}$ & $\begin{array}{l}\text { SGR } \\
\left(d^{-1}\right)\end{array}$ \\
\hline \multicolumn{8}{|c|}{ Latitud-I (April-May 1995) } \\
\hline ST-N $\left(24^{\circ} \mathrm{N}\right.$ to $\left.30^{\circ} \mathrm{N}\right)$ & $1.14 \pm 0.78$ & $0.0007 \pm 0.0003$ & $0.013 \pm 0.004$ & $0.07 \pm 0.02$ & $1.52 \pm 0.46$ & $0.05 \pm 0.01$ & $0.03 \pm 0.01$ \\
\hline $\mathrm{T}-\mathrm{N}\left(5^{\circ} \mathrm{N}\right.$ to $\left.24^{\circ} \mathrm{N}\right)$ & $0.31 \pm 0.08$ & $0.0025 \pm 0.0006$ & $0.055 \pm 0.016$ & $0.17 \pm 0.04$ & $3.04 \pm 0.83$ & $0.68 \pm 0.17$ & $0.14 \pm 0.02$ \\
\hline $\mathrm{Eq}\left(10^{\circ} \mathrm{S}\right.$ to $\left.5^{\circ} \mathrm{N}\right)$ & $0.36 \pm 0.12$ & $0.0441 \pm 0.0059$ & $0.086 \pm 0.037$ & $0.10 \pm 0.01$ & $8.92 \pm 0.84$ & $0.28 \pm 0.12$ & $0.02 \pm 0.01$ \\
\hline $\mathrm{T}-\mathrm{S}\left(22^{\circ} \mathrm{S}\right.$ to $\left.10^{\circ} \mathrm{S}\right)$ & $1.61 \pm 1.06$ & $0.0005 \pm 0.0004$ & $0.001 \pm 0.000$ & $0.16 \pm 0.06$ & $7.16 \pm 0.56$ & $0.14 \pm 0.02$ & $0.02 \pm 0.01$ \\
\hline ST-S $\left(35^{\circ} \mathrm{S}\right.$ to $\left.22^{\circ} \mathrm{S}\right)$ & $0.31 \pm 0.08$ & $0.0021 \pm 0.0005$ & $0.005 \pm 0.002$ & $0.13 \pm 0.01$ & $6.77 \pm 0.77$ & $0.22 \pm 0.07$ & $0.03 \pm 0.01$ \\
\hline \multicolumn{8}{|c|}{ Latitud-II (October-November 1995) } \\
\hline $\mathrm{ST}-\mathrm{N}\left(24^{\circ} \mathrm{N}\right.$ to $\left.30^{\circ} \mathrm{N}\right)$ & $37.07 \pm 36.69$ & $0.0011 \pm 0.0004$ & $0.019 \pm 0.002$ & $0.06 \pm 0.02$ & $10.98 \pm 2.86$ & $0.08 \pm 0.02$ & $0.01 \pm 0.00$ \\
\hline $\mathrm{T}-\mathrm{N}\left(5^{\circ} \mathrm{N}\right.$ to $\left.24^{\circ} \mathrm{N}\right)$ & $26.16 \pm 12.66$ & $0.1899 \pm 0.0903$ & $2.979 \pm 1.810$ & $0.38 \pm 0.14$ & $12.43 \pm 2.10$ & $8.84 \pm 2.02$ & $0.47 \pm 0.11$ \\
\hline Eq $\left(10^{\circ} \mathrm{S}\right.$ to $\left.5^{\circ} \mathrm{N}\right)$ & $130.82 \pm 100.95$ & $1.340 \pm 1.158$ & $16.944 \pm 12.63$ & $0.10 \pm 0.01$ & $10.97 \pm 1.70$ & $2.54 \pm 0.80$ & $0.19 \pm 0.06$ \\
\hline $\mathrm{T}-\mathrm{S}\left(22^{\circ} \mathrm{S}\right.$ to $\left.10^{\circ} \mathrm{S}\right)$ & $17.14 \pm 5.17$ & $0.0341 \pm 0.0223$ & $1.550 \pm 0.605$ & $0.03 \pm 0.01$ & $8.69 \pm 1.99$ & $1.84 \pm 0.75$ & $0.18 \pm 0.08$ \\
\hline ST-S $\left(35^{\circ} \mathrm{S}\right.$ to $\left.22^{\circ} \mathrm{S}\right)$ & $25.83 \pm 8.60$ & $0.0605 \pm 0.0190$ & $0.472 \pm 0.159$ & $0.08 \pm 0.01$ & $4.95 \pm 0.80$ & $1.63 \pm 0.79$ & $0.28 \pm 0.07$ \\
\hline
\end{tabular}



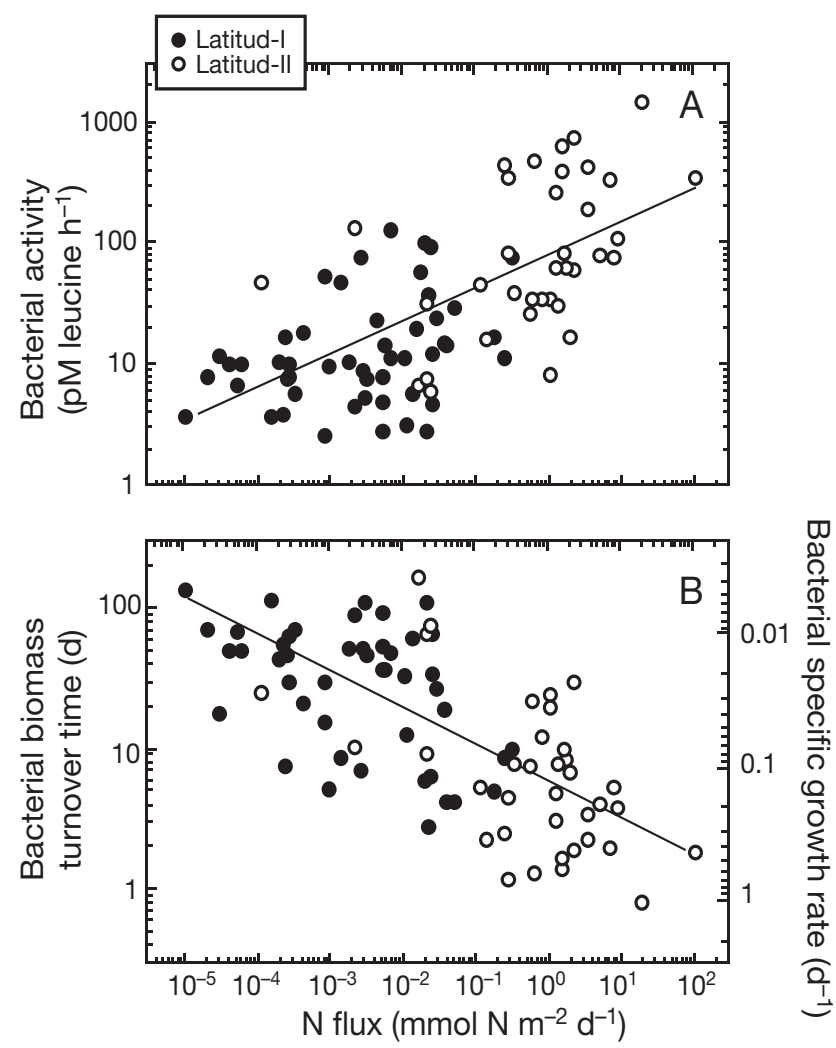

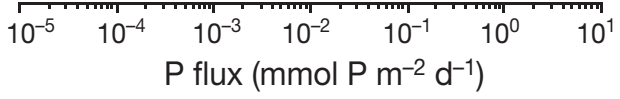

Fig. 2. Relationship between the upward diffusive flux of nutrients (nitrate + nitrite, and phosphate) through the thermocline and (A) bacterial activity (as leucine incorporation rates) and (B) bacterial growth. Solid lines correspond to the regression equations fitted to our data: Log bacterial activity $\left(\mathrm{pM} \mathrm{h}^{-1}\right)=1.87+0.27$; Log $\mathrm{N}$ flux $\left(\mathrm{mmol} \mathrm{N} \mathrm{m}^{-2} \mathrm{~d}^{-1}\right)$; Log turnover time $(\mathrm{d})=0.79-0.27$; Log $\mathrm{N}$ flux $(\mathrm{mmol} \mathrm{N} \mathrm{m})^{-2}$ $\mathrm{d}^{-1}$ ). $\mathrm{N}$ and $\mathrm{P}$ fluxes were strongly correlated, Log $\mathrm{N}$ fluxes $=$ $1.27( \pm 0.14)+1.11( \pm 0.05) ; \log$ P fluxes, $r^{2}=0.84$, with an average $\mathrm{N}: \mathrm{P}$ ratio of 18

nutrients (both $\mathrm{N}$ and $\mathrm{P}$, which were strongly intercorrelated, $\mathrm{r}=0.92, \mathrm{p}<0.0005)$, and bacterial activity and turnover rate in surface waters $(\mathrm{p}<0.0000005$ for both $\mathrm{N}$ and P inputs, Fig. 2). This relationship was consistent between cruises (Fig. 2) despite order-of-magnitude differences in water column stability and nutrient supply between them (Table 1). Where nutrient supply was low, as in the gyre areas, the doubling times of bacterial populations exceeded $50 \mathrm{~d}$, compared to about $1 \mathrm{~d}$ where nutrient supply was high, as in the equatorial upwelling zone and off the NW African upwelling zone (Fig. 2). The relationship between bacterial activity and nutrient supply was equally strong with either $\mathrm{N}$ or P supply, accounting for about half of the variance in bacterial activity $\left(\mathrm{r}^{2}\right.$ ranging from 0.44 to 0.47 ) despite the considerable uncertainty about the estimates of vertical nutrient supply derived here. The relationship between bacterial activity and nutrient supply did not only hold when examining rates of bacterial activity in surface waters, but also (and even better) when examined for vertically integrated rates (which were only available for the Latitud-II cruise, Fig. 3), indicating that the relationship between nutrient supply and surface bacterial activity (Fig. 2) holds within individual cruises and was not an artifact generated from the contrasting nutrient supply rates between cruises.

This relationship between nutrient supply and vertically integrated bacterial production (BP) for the Latitud-II cruise was best described by the regression equation:

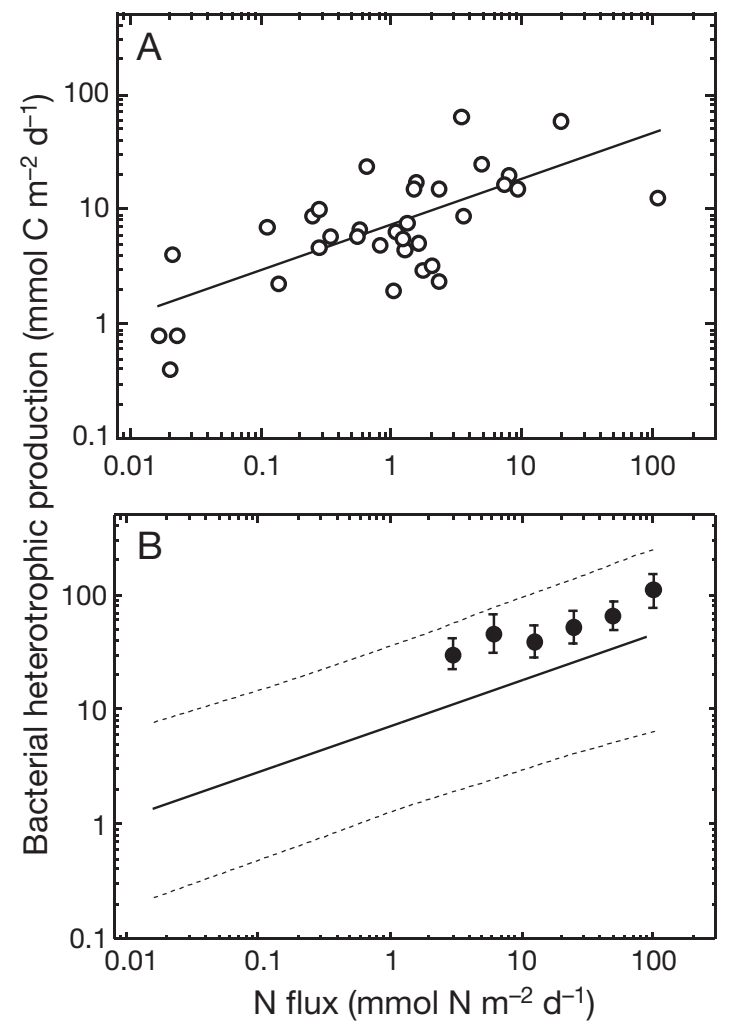

Fig. 3. (A) Relationship between the upward diffusive flux of nitrate + nitrite and the integrated heterotrophic bacterial carbon production over the mixed layer during the OctoberNovember (Latitud-II) cruise. The solid line corresponds to the fitted regression equation: Log bacterial $\mathrm{C}$ production $\left(\mathrm{mmol} \mathrm{C} \mathrm{m} \mathrm{d}^{-2} \mathrm{~d}^{-1}\right)=0.85+0.39 ; \log \mathrm{N}\left(\mathrm{mmol} \mathrm{N} \mathrm{m}^{-2} \mathrm{~d}^{-1}\right) ; \mathrm{n}=34$, $\mathrm{r}^{2}=0.48$. (B) Relationship between the nitrogen added to the Blanes Bay (NW Mediterranean) mesocosms and the time-integrated bacterial carbon production in the mesocosms (black dots $\pm \mathrm{SE}$ ), as compared to the upward diffusive flux of nitrate + nitrite and the depth-integrated bacterial carbon production over the mixed layer during the Latitud-II cruise (A). The solid line is that obtained in (A), and the other 2 lines are the prediction limits for the relationship 
Log Areal BP $\left(\mathrm{mmol} \mathrm{C} \mathrm{m} \mathrm{m}^{-2} \mathrm{~d}^{-1}\right)=0.85( \pm 0.06)$ $+0.39( \pm 0.07)$ Log $\mathrm{N}$ flux $\left(\mathrm{mmol} \mathrm{N} \mathrm{m} \mathrm{N}^{-2} \mathrm{~d}^{-1}\right)$

where $\mathrm{r}^{2}=0.48, \mathrm{n}=34, \mathrm{f}$-ratio $=29.9$, and $\mathrm{p}<0.00005$.

The slope was significantly $<1$ ( $t$-test, $\mathrm{p}<0.0005)$, indicating that the areal bacterial production per unit nitrogen input declines with increasing nutrient input. The tendency for areal bacterial production per unit nutrient input to decline with increasing nitrogen input implies that bacterial production must be recycled faster at low nutrient inputs. Indeed, grazer impact (expressed as the \% of bacterial production lost to grazing) was highest at low nutrient inputs, and decreased with increasing nutrient fluxes (VázquezDomínguez et al. 2005). The large scatter in these data and the limitations of the methods preclude the calculation of a significant estimate for the $\mathrm{C}: \mathrm{N}$ ratio of the bacterial production.

We also tested whether the relationship between bacterial activity and nutrient inputs was indirect, reflecting a possible link between particulate primary production (Table 2) and nutrient inputs. Neither chl a concentration nor particulate primary production (which were interrelated, Pearson's $r=0.55, p=0.006$ ) were significantly correlated to the nutrient inputs ( $\mathrm{r}$ for Nitrogen $=-0.027$ and -0.024 , respectively; $\mathrm{r}$ for Phosphorus $=-0.04$ and -0.032 , respectively; all $\mathrm{p}>$ 0.85), nor were they significantly related to bacterial abundance or activity (all $\mathrm{p}>0.05$ ). These results indicate bacterial activity to be (statistically) independent of the concurrent particulate primary production in the Central Atlantic, and provide evidence that the relationship between nutrient supply and bacterial activity reported here (Figs. $2 \& 3$ ) was not directly mediated by increased phytoplankton particulate production.

The generality of the relationship between nutrient supply and vertically integrated bacterial production derived from Eq. (1) was tested using results from a mesocosm experiment that applied increasing nutrient inputs to an oligotrophic coastal community. The aver-

Table 2. Mean $( \pm$ SE) integrated primary production $(\mathrm{PP})$ and bacterial production (BP) in the different regions occupied in the Latitud-II cruise. Partitioning of the Atlantic Ocean into biogeochemical provinces as in Table 1. n: number of vertical profiles integrated

\begin{tabular}{|c|c|c|c|c|}
\hline \multirow{2}{*}{ Area } & \multicolumn{2}{|c|}{$\longrightarrow \mathrm{PP}=$} & \multirow[b]{2}{*}{$\mathrm{n}$} & \multirow{2}{*}{$=\mathrm{BP}-\mathrm{mmolC} \mathrm{m}^{-2} \mathrm{~d}^{-1}$} \\
\hline & $\mathrm{n}$ & $\mathrm{mmolC} \mathrm{m}^{-2} \mathrm{~d}^{-1}$ & & \\
\hline \multicolumn{5}{|c|}{ Latitud-II (October-November 1995) } \\
\hline $\mathrm{ST}-\mathrm{N}\left(24^{\circ} \mathrm{N}\right.$ to $\left.30^{\circ} \mathrm{N}\right)$ & 2 & $82.98 \pm 31.68$ & 4 & $0.70 \pm 0.10$ \\
\hline $\mathrm{T}-\mathrm{N}\left(5^{\circ} \mathrm{N}\right.$ to $\left.24^{\circ} \mathrm{N}\right)$ & 7 & $114.70 \pm 60.76$ & 13 & $16.55 \pm 4.41$ \\
\hline $\mathrm{Eq}\left(10^{\circ} \mathrm{S}\right.$ to $\left.5^{\circ} \mathrm{N}\right)$ & 5 & $67.68 \pm 35.77$ & 8 & $18.36 \pm 7.00$ \\
\hline $\mathrm{T}-\mathrm{S}\left(22^{\circ} \mathrm{S}\right.$ to $\left.10^{\circ} \mathrm{S}\right)$ & 4 & $15.77 \pm 3.99$ & 8 & $12.16 \pm 2.81$ \\
\hline ST-S $\left(35^{\circ} \mathrm{S}\right.$ to $\left.22^{\circ} \mathrm{S}\right)$ & 6 & $85.97 \pm 13.63$ & 9 & $6.39 \pm 1.67$ \\
\hline
\end{tabular}

age bacterial production along the experimental period was strongly (Pearson's $r=0.98$, p < 0.0001) correlated to the nutrient input applied to each of the experimental mesocosms. Moreover, the empirically derived relationship between nutrient supply and vertically integrated bacterial production for the Central Atlantic (Eq. [1]) correctly predicted the average bacterial production derived from the experimental treatments, for all the experimentally derived values were within the broad confidence limits of the estimates (Fig. 3B). In this experiment, however, nutrient supply was significantly related to particulate primary production, which was also related to bacterial production (Duarte et al. 2000, authors' unpubl. data).

\section{DISCUSSION}

We report that bacterial activity throughout the Atlantic Ocean is independent of concomitantly measured phytoplankton variables (such as chlorophyll or particulate primary production), but that it is related to nutrient supply through the thermocline (Figs. $2 \& 3$ ). This challenges commonly accepted paradigms, but is supported by the good correlation encountered between bacterial abundances and water column stability (Fig. 1), as water column stability affects nutrient supply.

Bacterial abundance and activity showed considerable variability in the Central Atlantic in 1995, with values comparable to those reported for this region (Buck et al. 1996, Zubkov et al. 2000, Hoppe et al. 2002, Morán et al. 2004). However, while Zubkov et al. (2000) reported little change from September to October 1996 and April to May 1997, our results show order-of-magnitude differences in bacterial abundance and activity from March to April 1995 and October to November 1995. In particular, the average bacterial production during the Latitud-II cruise in October to November $1995\left(\sim 3 \mu g \mathrm{C} \mathrm{l}^{-1} \mathrm{~d}^{-1}\right)$ exceeded the values observed in any other published meridional study in the region. This cruise was characterized by intense mixing, resulting in a considerably greater diffusive nutrient supply to the photic layer than that observed during the Latitud-II cruise (Table 1). As a raw average, SST anomalies in the Latitud-I cruise were $\sim 1^{\circ} \mathrm{C}$ above average in the equatorial and southern tropical and subtropical areas, while they were $1^{\circ} \mathrm{C}$ below average in the Latitud-II cruise (data not shown). However, SST was similar between cruises in the subtropical 
northern areas, where we measured similar bacterial production values (Tables $1 \& 2$ ), on the same order as values found by others in the region (Morán et al. 2004. Marañón et al. 2007). Our bacterial production values for Latitud-I were, in contrast, slightly below those determined by Zubkov et al. (2000) and Hoppe et al. (2002) in cruises performed in different seasons. Values of particulate primary production were only obtained in Latitud-II (Table 2) and were, in general, slightly higher than those encountered in other studies (Marañón et al. 2007), particularly in the subtropical areas. These studies used whole-day incubations instead of the 1.5 to $3 \mathrm{~h}$ incubations we did, which might explain the differences encountered.

Our results suggest that the considerable variability, both temporal and spatial, in bacterial abundance and production in the Central Atlantic is linked to physical processes affecting water column stability (Fig. 1) and the diffusive vertical nutrient supply (Fig. 2). Intense mixing events, such as those conducive to the high nutrient supply and bacterial production in October to November 1995 have been reported to be a major driver of variability in planktonic processes in the subtropical ocean, where the passage of active storms has been linked to perturbations of biological processes (McNeil et al. 1999, Martin et al. 2005). Perturbations in the functioning of the planktonic communities in subtropical ocean gyres, such as those reported here, may be more common than hitherto considered, and driven also by mesoscale eddies (McGillicuddy et al. 1998, Mouriño-Carballido 2009), atmospheric disturbances (DiTullio \& Laws 1991), as well as large scale phenomena (e.g. El Niño Southern Oscillation-like phenomena, Karl et al. 1995, Lomas \& Bates 2004). Yet, the observations of such phenomena have been largely restricted to variability in phytoplankton abundance, which can be recorded through autonomous sensors (e.g. fluorescence), a technology not yet available to monitor bacterial abundance and activity. There is, however, some published evidence of effects of oceanic perturbations on microbe abundance and activity (e.g. Martin et al. 2005, Ewart et al. 2008).

We show here a robust relationship between bacterial abundance and the diffusional nutrient flux. Given that there always is some inter-sample variability in bacterial production measurements, and that the parameterization of the diffusion values allows only firstorder approximations (see 'Materials and methods'), the scatter encountered is reasonable. Our estimates of bacterial-specific growth rates (Fig. 2B) are, obviously, affected by the choices of conversion factors. Here we used an average of the empirically determined leucine-to-carbon conversion factors, even though it is well-known that these factors vary seasonally (AlonsoSáez et al. 2008), as well as spatially (Alonso-Sáez et al.
2007). We also used flow cytometry to estimate the cell size of the bacteria and a published relationship to estimate cell carbon from size. All contributing uncertainties to the estimate of growth rate and, together with the relatively inexact determination of nutrient fluxes, make the relationship found in Fig. 2B even more striking. Furthermore, our data are a snapshot of what occurs; how the bacterial community responds to different organic matter and nutrient inputs might vary in time and space.

In addition, our estimates of nutrient inputs ignore other possible sources, such as lateral and atmospheric inputs, which can be important in the ocean as well (McGillicuddy et al. 1998, Oschlies \& Garçon 1998, Duarte et al. 2006). Improvements in the estimates of both bacterial production and nutrient inputs will allow a better elucidation of the relationship between nutrient supply rates and bacterial production in the ocean. This suggestion is supported by the much stronger relationship between bacterial production and nutrient inputs derived when nutrient inputs were experimentally controlled (Fig. 3B), a relationship consistent with that derived from comparative analyses of bacterial production and calculated nutrient supply. The nitrogen experimental supply in the mesocosm experiment was in the form of ammonia, while the calculated fluxes in the Atlantic were for $\mathrm{NO}_{2}+\mathrm{NO}_{3}$. Our results seem to indicate that the functional relationship between nutrient supply and bacterial processes is similar, no matter what form of nitrogen is used. Oceanic bacteria may use diffused nutrients in their oxidized form, but it is likely that the diffused oxidized nutrients are immediately taken up and recycled to ammonia at the base of the photic layer.

There are certainly other factors that would contribute to uncoupling bacterial activity from particulate primary production. Inputs of labile DOC from secondary producers (Nagata 2000), or from bacteriophage activity pulses, could at times decouple the linkage between instantaneous primary production and bacterial activity.

In addition to providing evidence of bacterial responses to physical processes in the upper subtropical ocean, our observation of a relationship between dissolved inorganic nutrient supply and bacterial activity supports the growing evidence for a dependence of bacterial activity on nutrient inputs in the oligotrophic ocean (Pomeroy et al. 1995, Cotner et al. 1997, Rivkin \& Anderson 1997, Thingstad et al. 1998, Zohary \& Robarts 1998, Obernosterer et al. 2003, Zohary et al. 2005). Bacteria are known to be important contributors to dissolved inorganic nutrient uptake in the ocean, including the uptake of nitrate (Kirchman 2000), which suggest that they have the capacity to use new nitrogen. Increased upward nutrient fluxes are, 
therefore, expected to enhance both primary production and bacterial activity and it is possible that bacteria and phytoplankton may compete for nutrients, as suggested in the past (e.g. Suttle et al. 1990). Our results suggests that, at the time of the present study, bacterial production was relatively independent of concurrent particulate primary production in the Central Atlantic, consistent with reports of a 2 order-ofmagnitude variation in the percent bacterial production relative to primary production in the area (Hoppe et al. 2002).

It is possible that the observed relationship between nutrient supply and leucine incorporation might in some way be related to the recognized capacity of some algae to incorporate organic substrates (Paerl 1991). In particular, Prochlorococcus have been reported to incorporate amino acids, specifically methionine (Zubkov et al. 2003), with biomass-specific rates similar to those of other bacterioplankton (Zubkov et al. 2004). The fraction of total bacteria as Prochlorococcus during the Latitud-2 cruise, however, ranged from $<1$ to ca. $25 \%$ (average $14 \%$ ), but only in ca. $20 \%$ of the samples were Prochlorococcus $>20 \%$ of all prokaryotes - values similar to those found by others (Heywood et al. 2006). The contribution of Prochlorococcus to total bacterioplankton varies with the region sampled, and they might account for $1 \%$ to $20 \%$ of total amino acid-methionine- incorporation (Zubkov \& Tarran 2005). It is therefore unlikely that Prochlorococcus's incorporation of leucine, if it exists, could explain the global pattern we report.

If bacterial activity is relatively independent of concurrent particulate primary production, bacterial production should be partially supported, in addition to recently produced DOC, by the resident DOC pool, a pattern consistent with reports that bacteria in the oligotrophic ocean use old carbon, based on examination of the ${ }^{14} \mathrm{C}$ contents of bacterial DNA (Cherrier et al. 1999). Nutrient pulses, such as those provided by oceanic perturbations, could facilitate the use of semilabile DOC accumulated during periods of severe nutrient deficiency (Thingstad et al. 1997, Carlson et al. 2004), a possibility supported by evidence that nutrient supply facilitates the use of nutrient-poor DOC (Zweifel et al. 1993). The only experimental test of this idea published to date, however, does not support this possibility (Carlson et al. 2002). These experiments were done in an area that exhibited mainly carbon limitation of bacterial activity (Carlson \& Ducklow 1996, Carlson et al. 2002) and degradation of semi-labile DOC was dependent on the availability of readily degradable low molecular weight DOC on top of inorganic nutrients. Furthermore, Carlson et al (2004) experimentally demonstrated that bacterial community structure was one of the most important factors determining low-quality DOC degradation, on top of availability of inorganic nutrients and degradable DOC. Whether these results apply to a given set of oceanic conditions or can be extrapolated to the surface Atlantic as sampled in our study cannot be answered.

The decoupling that we observed between instantaneous primary and bacterial production might be one of the explanations for the dominance of bacterial respiration over primary production over large areas of the oligotrophic ocean. In our data base the average relationship bacterial production:primary production was, on average, $0.21 \pm 0.05$. This is fairly similar to previous comparative analyses (Cole et al. 1988, Ducklow 1999), but it varies greatly, with a higher ratio (up to 1 ), in the tropical region (Fig. 4, Table 2), as also recently reported by Hoppe et al. (2002). Bacterial C demand can be estimated for the central Atlantic using the empirical relationships of López-Urrutia \& Morán (2007) and while the production of DOC by autotrophs (dPP for dissolved primary production or EOC for excreted organic carbon) was not measured in the present study, it can be estimated from the quite robust relationships previously found in the area (cf. Teira et al. 2001). The values ranged from 3 to $28 \mathrm{mmolC} \mathrm{m}^{-2}$ $\mathrm{d}^{-1}$ (5 to $40 \%$ of particulate primary production [PP]). We calculated (details not shown) that dPP was more than enough to cover bacterial carbon demand in the northernmost and southernmost stations, but between $20^{\circ} \mathrm{N}$ and $20^{\circ} \mathrm{S}$, dPP would cover only $12 \%$ of bacterial demand, with values below $7 \%$ between $10^{\circ} \mathrm{N}$ and the equator. This is a value similar to that estimated by Robinson et al. (2002) for the Eastern Atlantic Ocean,

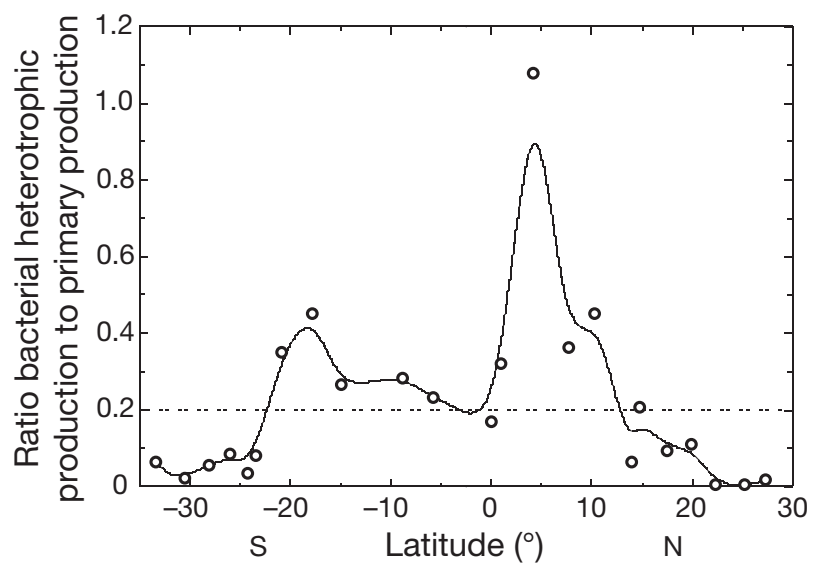

Fig. 4. Latitudinal distribution of the ratio of integrated bacterial production to particulate primary production during the October-November (Latitud-II) cruise. The horizontal line refers to the 0.2 ratio between bacterial and primary production, average of all data. The line is a smoothed Stineman function where each point is geometrically weighted with $\pm 10 \%$ of the data range 
indicating that dPP supplies only a few percent of bacterial carbon needs there. Neither dissolved nor particulate primary production would suffice to supply the large bacterial demand of carbon in that area. This calculated excess bacterial carbon use over primary production across much of the tropical Atlantic is consistent with similar calculations by Hoppe et al. (2002), and reports of heterotrophy in the Central Atlantic (Agustí et al. 2001, Duarte et al. 2001, Robinson et al. 2002). The possibility exists, however, that even a very small dPP contribution in the form of very labile $\mathrm{C}$ might stimulate simultaneous nutrient uptake and cometabolization of the resident $C$ pool. In that way, we would be observing apparent particulate PP and BP uncoupling, while in fact primary production and BP would be coupled through the direct use of dPP and the stimulation of $\mathrm{C}$ use by labile dPP.

The relationship between bacterial production and nutrient supply suggests order-of-magnitude increases in bacterial biomass and production in response to increased nutrient inputs in the oligotrophic ocean. If found to be general, this can help explain (1) the relatively large bacterial abundance and biomass supported by relatively low levels of primary producers in the oligotrophic ocean (Buck et al. 1996, Gasol et al. 1997); (2) the low bacterial growth efficiency (del Giorgio \& Cole 2000) and high bacterial respiration relative to primary production (del Giorgio et al. 1997) observed at low nutrient supply rates, since bacteria would grow on more recalcitrant organic substrates; and (3) the accumulation of DOC under severe nutrient limitation (Thingstad et al. 1997). Further, these findings may help explain the observed relationship between water column stability and oceanic DOC concentration (Tanoue 1993, Hansell \& Waterhouse 1997) because water stability constrains vertical nutrient supply and, therefore, bacterial activity within the mixed layer. Further confirmation of an important control of oceanic bacterial activity by nutrient inputs would require significant adjustments of the existing paradigms on the functioning of oceanic food webs.

Acknowledgements. This research was part of the LATITUD project (AMB94-0739), funded by the Spanish Interministerial Commission for Science and Technology, while writing was supported by projects COCA (REN2000-1471-CO2-01/MAR) and MODIVUS (CTM2005-04795/MAR). We thank the crew of RV 'Hespérides' for assistance; T. Granata, P. Jornet, A. Lucea, M. Manríquez, and M. Merino for help with data acquisition; T.H.S. Canut for encouragement; X.A.G. Morán, C. Pedrós-Alió, J. Arístegui, M. Latasa, X.A. Álvarez-Salgado, C. Marrasé, R. Massana and E. Sherr for helpful comments; and all who worked in the FHRL for various help. We are particularly thankful to M.P. Satta for the primary production determinations.

\section{LITERATURE CITED}

Agustí S, Duarte CM (1999) Phytoplankton chlorophyll a distribution and water column stability in the central Atlantic Ocean. Oceanol Acta 22:193-203

Agustí S, Duarte CM, Vaqué D, Hein M, Gasol JM, Vidal M (2001) Food web structure and elemental (C, N and P) fluxes in the Eastern tropical North Atlantic. Deep-Sea Res II 48:2295-2321

Alonso-Sáez L, Gasol JM, Arístegui J, Vilas JC, Vaqué D, Duarte CM, Agustí S (2007) Large-scale variability in surface bacterial carbon demand and growth efficiency in the subtropical North East Atlantic Ocean. Limnol Oceanogr 52:533-546

Alonso-Sáez L, Vázquez-Domínguez E, Cardelús C, Pinhassi $\mathrm{J}$ and others (2008) Factors controlling the year-round variability in carbon flux through bacteria in a coastal marine system. Ecosystems 11:397-409

Buck KR, Chavez FP, Campbell L (1996) Basin-wide distributions of living carbon components and the inverted trophic pyramid of the central gyre of the North Atlantic Ocean, summer 1993. Aquat Microb Ecol 10:283-298

Carlson CA, Ducklow HW (1996) Growth of bacterioplankton and consumption of dissolved organic carbon in the Sargasso Sea. Aquat Microb Ecol 10:69-85

Carlson CA, Giovannoni SJ, Hansell DA, Goldberg SJ and others (2002) Effect of nutrient amendments on bacterioplankton production, community structure, and DOC utilization in the northwestern Sargasso Sea. Aquat Microb Ecol 30:19-36

Carlson CA, Giovanonni SJ, Hansell DA, Goldberg SJ, Parsons R, Vergin K (2004) Interactions among dissolved organic carbon, microbial processes, and community structure in the mesopelagic zone of the northwestern Sargasso Sea. Limnol Oceanogr 49:1073-1083

Cherrier J, Bauer JE, Druffel ERM, Coffin RB, Chanton JP (1999) Radiocarbon in marine bacteria: evidence for the ages of assimilated carbon. Limnol Oceanogr 44:730-736

- Cole JJ, Findlay S, Pace ML (1988) Bacterial production in fresh and saltwater ecosystems: a cross-system overview. Mar Ecol Prog Ser 43:1-10

Cotner JB, Ammermann JW, Peele ER, Bentzen E (1997) Phosphorus-limited bacterioplankton growth in the Sargasso Sea. Aquat Microb Ecol 13:141-149

del Giorgio PA, Cole JJ (2000) Bacterial energetics and growth efficiency. In: Kirchman DL (ed) Microbial ecology of the oceans. Wiley-Liss, Wilmington, DE, p 289-325

del Giorgio PA, Davis J (2002) Patterns in dissolved organic matter lability and consumption across aquatic ecosystems. In: Findlay S, Sinsabaugh C (eds) Aquatic ecosystems: interactivity of dissolved organic matter. Academic Press, San Diego, CA, p 399-424

del Giorgio PA, Cole JJ, Cimbleris A (1997) Respiration rates in bacteria exceed phytoplankton production in unproductive aquatic systems. Nature 385:148-151

> DiTullio GR, Laws EA (1991) Impact of an atmosphericoceanic disturbance on phytoplankton community dynamics in the North Pacific Central Gyre. Deep-Sea Res 38: $1305-1329$

Duarte CM, Agustí S, Gasol JM, Vaqué D, VazquezDomínguez E (2000) Effect of nutrient supply on the biomass structure of planktonic communities: an experimental test on a Mediterranean coastal community. Mar Ecol Prog Ser 206:87-95

Duarte CM, Agustí S, Arístegui J, González N, Anadón R (2001) Evidence for a heterotrophic subtropical northeast Atlantic. Limnol Oceanogr 46:425-428 
Duarte CM, Dachs J, Llabrés M, Alonso-Laita P and others (2006) Aerosol inputs enhance new production in the subtropical northeast Atlantic. J Geophys Res 111:G04006. doi:10.1029/2005JG000140

Ducklow HW (1999) The bacterial component of the oceanic euphotic zone. FEMS Microbiol Ecol 30:1-10

- Ewart CS, Meyers MK, Wallner ER, McGillicuddy DJ, Carlson CA (2008) Microbial dynamics in cyclonic and anticyclonic mode-water eddies in the northwestern Sargasso Sea. Deep-Sea Res II 55:1334-1347

Gasol JM, del Giorgio PA (2000) Using flow cytometry for counting natural planktonic bacteria and understanding the structure of planktonic bacterial communities. Sci Mar 64:197-224

Gasol JM, del Giorgio PA, Duarte CM (1997) Biomass distribution of marine planktonic communities. Limnol Oceanogr 42:1353-1363

Granata TC, Wiggert J, Dickey T (1995) Trapped, near-inertial waves and enhanced chlorophyll distributions. J Geophys Res 100:20793-20804

> Hansell DA, Waterhouse TY (1997) Controls on the distribution of organic carbon and nitrogen in the eastern Pacific Ocean. Deep-Sea Res I 44:843-857

Heywood JL, Zubkov MV, Tarran GA, Fuchs BM, Holligan PM (2006) Prokaryoplankton standing stocks in oligotrophic gyre and equatorial provinces of the Atlantic Ocean: Evaluation of inter-annual variability. Deep-Sea Res II 53:1530-1547

Hoppe HG, Gocke K, Koppe R, Begler C (2002) Bacterial growth and primary production along a north-south transect of the Atlantic Ocean. Nature 416:168-171

Karl DM, Letelier R, Hebel D, Tupas L, Dore J, Christian J, Winn C (1995) Ecosystem changes in the North Pacific subtropical gyre attributed to the 1991-92 El Niño. Nature 373:230-234

Kirchman DL, K'nees E, Hodson R (1985) Leucine incorporation and its potential as a measure of protein synthesis by bacteria in natural aquatic systems. Appl Microb Ecol 49:599-607

Kirchman DL (2000) Uptake and regeneration of inorganic nutrients by marine heterotrophic bacteria. In: Kirchman DL (ed) Microbial ecology of the oceans. Wiley-Liss, Wilmington, DE, p 261-288

- Lewis MR, and others (1986) Vertical nitrate fluxes in the oligotrophic ocean. Science 234:870-873

Lomas MW, Bates NR (2004) Potential controls on interannual partitioning of organic carbon during the winter/spring phytoplankton bloom at the bermuda atlantic time-series study (BATS) site. Deep-Sea Res I 51:1619-1636

López-Urrutia A, Morán XAG (2007) Resource limitation of bacterial production distorts the temperature dependence of oceanic carbon cycling. Ecology 88:817-822

Marañón E, Pérez V, Fernández E, Anadón R and others (2007) Planktonic carbon budget in the eastern subtropical North Atlantic. Aquat Microb Ecol 48:261-275

Martin AP, Zubkov MV, Burkill PH, Holland RJ (2005) Extreme variability in marine picoplankton and its consequences for interpreting Eulerian time-series. Biol Lett 1:366-369

McGillicuddy DJ Jr, Robinson AR, Siegel DA, Jannasch HW and others (1998) Influence of mesoscale eddies on new production in the Sargasso Sea. Nature 394:263-266

McNeil J, Jannasch H, Dickey T, McGillicuddy D, Brzezinski M, Sakamoto C (1999) New chemical, bio-optical and physical observations of upper ocean response to the passage of a mesoscale eddy off Bermuda. J Geophys Res 104:15537-15548
Morán XAG, Fernández E, Pérez V (2004) Size-fractionated primary production, bacterial production and net community production in subtropical and tropical domains of the oligotrophic NE Atlantic in autumn. Mar Ecol Prog Ser 274:17-29

Mouriño-Carballido B (2009) Eddy-driven pulses of respiration in the Sargasso Sea. Deep-Sea Res I 56(8):1242-1250

Nagata T (2000) Production mechanisms of dissolved organic matter. In: Kirchman DL (ed) Microbial ecology of the oceans, 1st edn. Wiley-Liss, Wilmington, DE, p 121-152

Norrman B, Zweifel UL, Hopkinson CS, Fry B (1995) Production and utilization of dissolved organic carbon during an experimental diatom bloom. Limnol Oceanogr 40:898-907

> Obernosterer I, Kawasaki N, Benner R (2003) P-limitation of respiration in the Sargasso Sea and uncoupling of bacteria from P-regeneration in size-fractionation experiments. Aquat Microb Ecol 32:229-237

Osborn TR (1980) Estimates of the local rate of vertical diffusion from dissipation measurements. J Phys Oceanogr 10:83-89

Oschlies A, Garçon V (1998) Eddy-induced enhancement of primary production in a model of the North Atlantic Ocean. Nature 394:266-269

Paerl HW (1991) Ecophysiological and trophic implications of light-stimulated amino acid utilization in marine picoplankton. Appl Environ Microbiol 57:473-479

> Pomeroy LR, Sheldon JE, Sheldon WM, Peters F (1995) Limits to growth and respiration of bacterioplankton in the Gulf of Mexico. Mar Ecol Prog Ser 117:259-268

> Prospero JM, Barrett K, Church T, Dentener F and others (1996) Atmospheric deposition of nutrients to the North Atlantic Basin. Biogeochemistry 35:27-73

Rivkin RB, Anderson MR (1997) Inorganic nutrient limitation of oceanic bacterioplankton. Limnol Oceanogr 42:730-740

Robinson C, Serret P, Tilstone G, Teira E, Zubkov MV, Rees AP, Woodward EMS (2002) Plankton respiration in the Eastern Atlantic Ocean. Deep-Sea Res I 49:787-813

Suttle CA, Fuhrman JA, Capone DG (1990) Rapid ammonium cycling and concentration-dependent partitioning of ammonium and phosphate: Implications for carbon transfer in planktonic communities. Limnol Oceanogr 35: $424-433$

> Tanoue E (1993) Distributional characteristics of DOC in the Central Equatorial Pacific. J Oceanogr 49:625-639

Teira E, Pazó MJ, Serret P, Fernández E (2001) Dissolved organic carbon production by microbial populations in the Atlantic Ocean. Limnol Oceanogr 46:1370-1377

Thingstad TF, Hagström Å, Rassoulzadegan F (1997) Accumulation of degradable DOC in surface waters: Is it caused by a malfunctioning microbial loop? Limnol Oceanogr 42:398-404

Thingstad TF, Zweifel UL, Rassoulzadegan F (1998) P limitation of heterotrophic bacteria and phytoplankton in the northwest Mediterranean. Limnol Oceanogr 43:88-94

> Vázquez-Domínguez E, Gasol JM, Agustí S, Duarte CM, Vaqué D (2005) Growth and grazing losses of prokaryotes in the Central Atlantic Ocean. J Plankton Res 27: 1055-1066

Vidal M, Duarte CM, Agustí S (1999) Dissolved organic nitrogen and phosphorus pools and fluxes in the central Atlantic Ocean. Limnol Oceanogr 44:106-115

- Williams PM, Druffel ERM (1987) Radiocarbon in dissolved organic matter in the central North Pacific Ocean. Nature 330:246-249

Zohary T, Robarts RD (1998) Experimental study of microbial $\mathrm{P}$ limitation in the eastern Mediterranean. Limnol Oceanogr 43:387-395 
Zohary T, Herut B, Krom MD, Mantoura RFC and others (2005) P-limited bacteria but N and P co-limited phytoplankton in the Eastern Mediterranean - a microcosm experiment. Deep-Sea Res II 52:3011-3023

Zubkov MV, Tarran GA (2005) Amino acid uptake of Prochlorococcus spp. in surface waters across the South Atlantic Subtropical Front. Aquat Microb Ecol 40: 241-249

Zubkov MV, Sleigh MA, Burkill PH, Leakey RJG (2000) Bacterial growth and grazing loss in contrasting areas of North and South Atlantic. J Plankton Res 22:685-711

Zubkov MV, Sleigh MA, Burkill PH (2001) Heterotrophic bacterial turnover along the $20^{\circ} \mathrm{W}$ meridian between $59^{\circ} \mathrm{N}$

Editorial responsibility: Craig Carlson,

Santa Barbara, California, USA and $37^{\circ} \mathrm{N}$ in July 1996. Deep-Sea Res II 48:987-1001

Zubkov MV, Fuchs BM, Tarran GA, Burkill PH, Amann R (2003) High rate of uptake of organic nitrogen compounds by Prochlorococcus cyanobacteria as a key yo their dominance in oligotrophic oceanic waters. Appl Environ Microbiol 69:1299-1304

Zubkov MV, Tarran GA, Fuchs BM (2004) Depth related amino acid uptake by Prochlorococcus cyanobacteria in the Southern Atlantic tropical gyre. FEMS Microbiol Ecol 50:153-161

> Zweifel UL, Norrman B, Hagström Å (1993) Consumption of dissolved organic carbon by marine bacteria and demand for inorganic nutrients. Mar Ecol Prog Ser 101:23-32

Submitted: November 8, 2007; Accepted: April 21, 2009

Proofs received from author(s): June 26, 2009 